Available Online at http://journal.unismuh.ac.id/index.php/otoritas

Otoritas : Jurnal Ilmu Pemerintahan, 8 (1), April 2018, 32-43

\title{
The Women Representation Policy and its Effect to Women Political Participation in Jember, Indonesia
}

\author{
Ria Angin ${ }^{1,2 *}$, Hary Yuswadi' ${ }^{1}$, Himawan Bayu Patriadi1, Nur Dyah Gianawati1 \\ ${ }^{1}$ Postgraduate School of Administration Studies, Faculty of Social and Political Sciences, \\ Universitas Jember, Jln. Kalimantan No. 37, Kab. Jember, Jawa Timur 68121, Indonesia. \\ ${ }^{2}$ Department of Governmental Science, Faculty of Social and Political Sciences, \\ Universitas Muhammadiyah Jember, Jln. Karimata No.49, Kab. Jember, Jawa Timur 68121, Indonesia.
}

Received: 23 November 2017; Revised: 12 March 2018; Accepted: 14 March 2018

\begin{abstract}
The journey of the Indonesian government in implementing women representation policy has evolved. In the election of 2004, women representation policies have not mentioned the target of achievement for political parties. The policy only states that political parties are expected to implement gender equality in nominating candidates. Then in the year of 2009 election, the government had changed the policy clause, and states the percentage that must be achieved by political parties. However, in 2004 and 2009 election only a few political parties, implemented the policy. Yet, the policy, which is implemented, in the 2014 election has changed. The clause of the policy became more distinct, for it contains sanctions which are applicable to any political parties that are not implementing the policy. The present study yielding that the more distinct the policy, the more likely it would be complied by all participating political parties. The effect of the complying political parties would be the increase of women participation in politics as candidates of legislatives.
\end{abstract}

Keywords: Women Quota; Women Representation Policy; Women Political Participation

How to Cite: Angin, R., Yuswadi, H., Patriadi, H. B., \& Gianawati, N. D. (2018). The Women Representation Policy and its Effect to Women Political Participation in Jember, Indonesia. Otoritas : Jurnal Ilmu Pemerintahan, 8(1), 32-43.

Permalink/DOI: https://doi.org/10.26618/ojip.v8i1.960

${ }^{*}$ Corresponding Author.

E-Mail : ria.angin@unmuhjember.ac.id

Copyright (C) 2018, Otoritas : Jurnal Ilmu Pemerintahan, ISSN: 2088-3706 (Print), ISSN: 2502-9320 (Online) 
Available Online at http://journal.unismuh.ac.id/index.php/otoritas

Otoritas : Jurnal Ilmu Pemerintahan, 8 (1), April, 2018, 33

\section{INTRODUCTION}

Enhancing of women's political participation program, to achieve equality with men, has been implemented by developed countries at 10-15 years before the Beijing conference, in 1995. While developing countries are implementing the same program, Beijing conference (Mussarat, Jabeen \& Sajid, 2017). There are two methods that have been tried to be implemented by applying quotas in the constitution or legislation and quotas through policy, which are implemented in political parties (Rahmatunnisa, 2016).

Indonesia as one of the countries that have agreed in the Beijing conference, implement it through the policy of women representation. This policy has been implemented for three election periods. The first implementation was in the election of 2004, then in the election of 2009 , and finally the policy was implemented in the election of 2014. During the three election periods, there has been an evolution of women's representation policy clause.

When the policy was implemented for the first time, the clause only stated, that a political party could nominate woemn as candidates. But this policy was so weak and has no power, to force all political parties to recruit women as candidates. The articles of this policy were not clearly, there were no information about the percentage of women to be recruited. As a result, not all political parties which participated in the 2004 elections implemented the policy. The government then changed the policy and showing the percentage of women candidates which must be achieved by political parties. But unfortunately not all political parties are triggered to achieve the target of $30 \%$ quota of women legislative candidates. Then when the 2014 election will be held, the election commission interpreted the policy and regulate PKPU No $7 / 2013$, which contains the clause of sanctions. Since then, the PKPU No. $7 / 2013$ becomes the trigger of political parties in realizing the quota of $30 \%$ of women candidates.

The implementation of women representation has drawn more interests for researchers. The gender quota has been implemented worldwide and become a fast track for enhanching the women representation. This policy have been enhanched women representation in the Polish parliament (Gwiazda, 2016). This policy has also been implemented in various countries and has succeeded in increasing women's representation.

This women representation policy would empower women not only in parliaments, but they could also ensure their positions in political parties, state committees and government offices at a certain percentage (Rosen, 2017). Although when the quota policy is fully implemented, it would threaten the reigning rules, practices and norms of political life, long premised upon women is exclusion (Krook, 2014).

Meanwhile, the gender quota policy would be successfully implemented, if there are some factors like the distinct and clear regulations, politics education, women empowerment, public campaign through media, mobilization of women movement networks, and politics education which eliminates any ideological and cultural constraints for women to be actively involved in public. Yet, it has been found that the implementation of women representation was hindered by the societal culture. Kang states in his study that bahwa the policy implementation is also constrained by the patriarchy culture (Kang, 2013). Furthermore, Ndirangu also indicates that the patriarchal structure within parties, state and people lives has a deleterious influence on the level of women's political participation and this hinges on the fact that despite the twothirds gender rule the representation of women in leadership position was low 
Available Online at http://journal.unismuh.ac.id/index.php/otoritas

Otoritas : Jurnal Ilmu Pemerintahan, 8 (1), April, 2018, 34

(Ndirangu, 2017). Cultural aspects as a constraint in political parties have also occurred by O'Brien \& Piscopo, who state that "Institutional, organizational and structural barriers - such as masculine cultures and male - dominated political parties - limit women's abilities to exercise their talents and qualifications" (O’Brien and Piscopo, 2017).

Therefore, it is vital for the policy implementers to understand to the deep about the political landscape in which social and political actors operate as a constantly shifting field of action both contextually and temporally is very important (Cornwall , 2017). That the societal culture is hard to change, Paxton in his study mentions one possible thing to be done, which is to make the policy more effective through changes in the norms that rule the women participation in politics (Paxton, 2015). This statement, however, has been argued by Bjarnegard by stating that activating regulations would only make the political parties better at implementing the letter of the law, and they do not get more women elected (Bjarnegard, 2016).

The statements by experts in their studies indicates that the women representation which is known as the quota law is very significant. Recruitment of women candidates is done by implementing quota policy. Despite this, the implementation of women representation policy is not yet effective as it is hindered by the patriarchy culture. Therefore, to make its implementation more sound and effective, it is vital to conduct reconstruction towards the societal culture. Another possible attempt is to create regulations containing norms aimed to enhance women participation. Yet, the political parties have only succeeded to implement the policy without actually increasing the number of women participation in politics. Therefore, based on the explanation stated in the statements seemingly the implemented policy without any sanc- tion clause has not been distinct enough to push the political parties to achieve the target of the policy.

Administratively, the implemented policy clause has included a manual containing instructions for the political parties. How the political parties implement the policy is highly dependent on the clause. Unless the policy clause is distinct, the political parties would tend to disobey it. Moreover, if the policy clause is distinct, coupled with sanctions, it is assumed that the political parties would comply with the policy, making a way to the achievement of the policy target.

So this article will discuss the evolutionary journey of women's representation policy in Indonesia, through micro research in Jember District. This micro study argues that patriarchal culture is not a barrier for women to participate as candidates, if there is a policy which guarantees for the role of women in politics.

\section{RESEARCH METHODS}

This research article was held in Jember, Indonesia. This research uses descriptive qualitative method and sources of data are the political parties officials, the electoral commission district of Jember, the women candidates which involved in the implementation of women political representation policy. Data collection method used is indepth interviews, and documentation. Data were analyzed using descriptive qualitative method.

\section{RESULTS AND DISCUSSION}

\section{The Evolution of Women Representa- tion Policy in Indonesia}

Since the signing of the agreement on the International Convention on the Elimination of All Forms of Discrimination Against Women (CEDAW) on 18 December 1979 and its implementation on September 3, 1981 and the conduct of Beijing Declaration, and Platform for Ac- 
tion in 1995, the Indonesian government is trying to implement throughthe women representation policy. The first time, the policy of women's representation was regulated in the Election Law No. $12 / 2003$ and implemented in the 2004 general election. Then the second, in the 2009 elections, the government implemented the same policy in the Election Law no. 10/2008. Then the third time, the government declared the Election Law no. $8 / 2012$ which is implemented in the 2014 election.The clauses of women's representation policy in the three Electoral Laws differ from one another and substantively show an evolutionary change.

Changes in clauses, especially on (1) mechanisms of nomination, (2) placement of women candidates in the list, and (3) determination of eligible candidates. In the Election Law no. 12/2003 and the Election Law no. $10 / 2008$ there is no clause for every political party, to achieve, the quota of $30 \%$ of female candidates.

The clause written in Election Law no. 12/2003: ".... may nominate candidates for members of DPR, Provincial DPRD and Regency / Municipal DPRD for each electoral district ....".Because, the sentences written in the clause, do not, indicate the order to implement, many political parties interpret that, the policy, does not have to be implemented. An informant initialed $\mathrm{K}$ who became commissioner of Jember District Election Commission for the period of 2004-2009 and 2009-2014 when asked why not all political parties implement the policy, she gave information that the factor is because the policy clause is not clear.

As a result, in the 2004 elections, only ten (10) political parties from the twenty-four (24) political parties, succeeded in recruiting candidates to $30 \%$.The ten parties include the Social Democratic Labor Party, the Merdeka Party, the New Indonesia Democratic Party, the Democratic Party, the Justice and Unity Party of Indonesia, the National Ama- nah Party, the National Concern Party, the Prosperous Justice Party, the Golkar Party and the Indonesian Union Party.Fourteen other political parties did not reach the $30 \%$ quota. Based on the rules, then to fourteen (14) political parties, did not get, sanctions.The electoral commission of district of Jember only has the authority to make public announcements through mass media both print and electronic. The government hopes, by this announcement the public will know there are ten (10) political parties that have reached the policy target and there are fourteen (14) political parties that do not reach the policy.Announcements are also communicated directly through community organizations.One of them was carried out by election commissioners during the regular meeting of the Jember Women's Organization (GOW) during the 2004 election campaign. The information provided by Election Commissioners complements the "women select women" campaign promoted by women activists at the time.However, according to informant $\mathrm{R}$, the information conveyed by the election commissioner herself is not sufficiently influential on the acquisition of votes obtained by political parties in the election.

Success in achieving implementation targets has no impact on the acquisition of seats. This experience has attracted the attention of the policy formulation actors.The women's representation policy clause that was implemented in the 2009 elections was changed to be more assertive. The clause is contained in the Election Law no. 10/2008 of article 53 no longer appeals but already mentions the $30 \%$ quota as follows: "the list of candidates referred to in article 52 contains at least 30\% female representation".

Although, the policy has been regulated the percentage of the number of women candidates, which must be achieved by political parties, in fact not all political parties reach the target successfully. As well as the implementation of 
policies in the 2004 elections, only a few political parties have reached the target.There are 24 political parties have become, contestants, but only 10 reached the target. Those are The Social Democratic Labor Party (PBSD), the Freedom Party, the New Indonesian Democratic Party (PPIB), the Democratic Party, the Justice and Unity Party of Indonesia (PKPI), the National Mandate Party (PAN), the National Concerned Party (PKPB), the Prosperous Justice Party (Partai Keadilan Sejahtera) PKS), Golkar Party (Golkar) and United Indonesian Party (PSI).

The policy clause, only mention the importance of increasing women candidates and does not mention the percentage that must be achieved by political parties clearly. Then in the 2009 election, the policy clause has changed and mentioned the number of $30 \%$ women legislative candidates, that must be achieved by every political party.

In Law No. 8/2008, which was implemented in the 2009 elections, article 55 states: "in the list of prospective candidates as referred to in paragraph 1 , in every 3 candidates there shall be at least one candidate. This regulation has an impact that in every 3 (three) candidates, women's candidates can be placed in the order of 1 , or 2 or 3 and so on not only in serial numbers 3,6 and so on.

There are fifteen (15) political parties that succeeded in reaching the quota of $30 \%$ of female candidates include: People's Conscience Party (Hanura), Karya Peduli Bangsa (PKPB) Party. The National People's Concern Party (PKN), the Sovereignty Party (PKS), the Regional Unity Party (PPD), the Democratic Reform Party (PDP), the Working Party for Development (PKB), the Indonesian Democratic Enforcement Party (PPDI), Golkar Party, Prosperous Peace Party (PDS), Indonesian National Bull Populist Party (PNBKI), National Awakening Party of Ulama (PKNU).
The general election commission adds KPU Regulation No. 7/2013 with sanctions for political parties, which, have failed in achieving the target of 30\%. These sanctions are effective in improving the performance of political parties when implementing policies. All political parties that become electoral contestants reach the target of $30 \%$. The Democratic Party reached $44 \%$, followed by the Prosperous Justice Party by $39 \%$, and the Justice and Peduli Indonesia Party (PKPI) of $38.1 \%$.The average number of policy implementation targets per political party is $36.9 \%$.

\section{Regulation of the General Election Commission (PKPU) No 7/2013}

Sanctions in PKPU No. 7/2013 get criticized, because the clause is contrary to the Election Law no 8/2012. The clause in the Election Law No. 8/2012 especially in articles, number 53, 55 and 56, does not mention any sanctions for political parties that do not reach the target of $30 \%$.

Reaction came from several officials. One of them is a member of Commission II of DPR RI. As quoted in the Sindonews.com, on April 10, 2013, that PKPU No.7 / 2013 must be immediately revised because it contradicts with the spirit of UU Pemilu No.8 / 2012. It further said that the KPU has caused new-style of discrimination because it imposes a threat of not involving a political party in a diagonal if the representation of women in the $30 \%$ list of candidates (DCS) is not achieved.

Another response came from the UIN Syarif Hidayatullah scientist, Saleh Dauly, who said that the $30 \%$ quota of women representation as a legislative candidate must be fulfilled by political parties has triggered the liberalization in politics in Indonesia. According to him, the clause of sanctions in PKPU No. $7 / 2013$ is unfair to male candidates.

The Electoral Commision (KPU) was 
Available Online at http://journal.unismuh.ac.id/index.php/otoritas

Otoritas : Jurnal Ilmu Pemerintahan, 8 (1), April, 2018, 37

also criticized by the Election Supervisory Board (Bawaslu). According to Bawaslu, KPU has exceeded its authority. Because in the Election Law No. 8/2012 there is a clause stating that if a political party can not achieve $30 \%$ quota then the incomplete file will be returned to the party's political committee to be fulfilled.If the political party still can not reach the $30 \%$ quota then the KPU will announce it to the public. But the KPU has deliberately violated this clause, and amended the provision by directly stating that a political party that can not fulfill it is declared an ineligible political party.The political party was immediately sanctioned not to follow the election in the electoral district.

Although the sanctions clause, which is regulated by the election commission are criticized this institution and gets support from various community groups. One of them is the Indonesian Women's Coalition (KPI). KPI members from various cities in Indonesia held a demo, as a form of support in increasing women's representation in politics. Fortunately, the number

Table 1. Results of 30\% Quota Policy Implementation of Women's Representation in Jember, Indonesia

Source: Secondary data that is processed

\begin{tabular}{ccc}
\hline Year & \% Female & \% Male \\
\hline 2004 & $120(22,51)$ & $413(77,48)$ \\
2009 & $213(28,21)$ & $542(71,78)$ \\
2014 & $212(36,69)$ & $362(63,06)$ \\
\hline
\end{tabular}

Table 2. The implementation results of Law No. 8/2012 and PKPU No.7/2013

in Jember, Indonesia

Source: Secondary data that is processed

\begin{tabular}{llccccc}
\hline No & $\begin{array}{c}\text { Political } \\
\text { party }\end{array}$ & $\begin{array}{c}\text { Number of female } \\
\text { candidates }\end{array}$ & $\mathbf{\%}$ & $\begin{array}{c}\text { Number of male } \\
\text { candidates }\end{array}$ & \% & Total \\
\hline 1. & Nasdem & 17 & 34 & 33 & 66 & 50 \\
2. & PKB & 16 & 35 & 30 & 65 & 49 \\
3. & PKS & 19 & 39 & 30 & 61 & 49 \\
4. & PDIP & 15 & 36,5 & 26 & 64,5 & 41 \\
5. & Golkar & 19 & 38 & 31 & 62 & 50 \\
6. & Gerindra & 17 & 34 & 33 & 66 & 50 \\
7. & Demokrat & 22 & 44 & 28 & 56 & 50 \\
8. & PAN & 18 & 37 & 31 & 63 & 49 \\
9. & PPP & 18 & 37,5 & 30 & 62,5 & 48 \\
10. & Hanura & 18 & 36 & 32 & 64 & 50 \\
11. & PBB & 17 & 34,7 & 32 & 65,3 & 49 \\
12. & PKPI & 16 & 38,1 & 26 & 61,9 & 42 \\
& Jumlah & 212 & 36,69 & 362 & 63,06 & 574 \\
\hline
\end{tabular}


Available Online at http://journal.unismuh.ac.id/index.php/otoritas

Otoritas : Jurnal Ilmu Pemerintahan, 8 (1), April, 2018, 38

that has supported the KPU more than those who have criticized it. Then the people who have criticized also have not brought their criticism to the court. That is why they have no legal power to cancel PKPU No. 7/2013. Therefore, what has been criticized has no effect on the behavior of political parties. They continue to implement the policy, and achieve the target of $30 \%$ quota of women representation as candidates. Presumably, this is the cause of the increasing number of political parties, which implements the policy. As shown in Table 1, the increase of political parties in implementing the policy affects the number of women who become legislative candidates.

Table 1 shows the success of the policy, in achieving the target of $30 \%$ of female candidates. The data in 2004 showed, when the policy was unclear, and only requested, to all political parties, to implement the policy, but without clear regulatory rules, only $22.51 \%$, women candidates were recruited. Whereas in the election year of 2009, when the women's representation policy stated that $30 \%$ of women candidates had to be reached by political parties, but the policy did not regulate the sanction clause, the target achieved was not up to $30 \%$, as regulated, and only reached an average of $28.21 \%$. But when the implemented policy regulates sanctions for political parties that do not achieve targets in each electoral area, the targets are successfully achieved by political parties. Percentage of achievements of each political party is greater than the minimum targeted. In table 2 has been listed, the percentage of each political party.

Based on table 2, there are three political parties that achieve the highest ranking: Democratic Party (44\%), PKS (39\%) and PKPI (38.1\%). The data in table 2 shows that policy sanctions have become coercive forces for policy implementers, to achieve, the targets of the policy. Another undeniable factor is that the political parties are those participating in the election, with one common purpose; to win the election. But the requirement to be an election contestant is, reaching the target of $30 \%$, women candidates in every electoral area. If it fails, then the political party will get sanction from the election commission. Sanctions from the Election Commission, are excluded, from the list of contestants in the electoral districts, which do not reach the $30 \%$ target.

So the sanctions clause that has been regulated in PKPU No. 7/2013 is a kind of guidance for political parties, to be careful when implementing policies. The clause of sanctions, in PKPU No. 7/2013, has an effect on the behavior of political parties, when recruiting women candidates. In the 2014 election, all political parties which registered as the 2014 election contestant are trying to reach the target of $30 \%$. This situation was different in the elections of 2004 and 2009, when the election commission did not regulate sanctions. In the two periods of election, 2004 and 2009, the performance of political parties in implementing the policy was not optimum.

This study, proves, that the behavior of political parties in recruiting candidates for legislative members can be improved, if the policy which is implemented, contains a clause of sanctions. This finding is in line with Kang's opinion.The policy design determines the behavior of actors in implementing policies (Kang, 2013).

\section{Post-Implementation Policy Verifica- tion}

The twelve political parties that have implemented the policy, are verified by the election commission. Verification includes candidate documents and all matters relating to candidacy in the 2014 election. The verification result is becomes a quality assurance for the quality of the candidate. This verification was done from 23 April 2013 until 6 May 
Available Online at http://journal.unismuh.ac.id/index.php/otoritas

Otoritas : Jurnal Ilmu Pemerintahan, 8 (1), April, 2018, 39

2013, following the registration done by the political parties. The first step is to check the completeness of the requirement files for the candidacy of legislatives, as regulated in Law of Election No. 8/2012. Other than the aforementioned files, other data observed by the committee is the status of every candidate. Any candidate involved in law cases would not pass this process. Verification of candidate documents, which have been registered as temporary candidates, are strict. But if during the document verification process, has been found, the data indicating, a candidate, who is involved in a legal case, then the candidate will be canceled.

The verification was conducted following the applicable schedule, particularly from 9 to 22 August 2013 and announced to public through local newspapers on 23 to 25 August tahun 2013. The verification results are then submitted to political parties. Furthermore, the candidates, who have been verified, then reported in the local newspaper "Radar Jember" and the local TV "Jember TV (JTV)" to get a response from the public. If any public object to the candidate, the candidate may fail to be nominated. Candidates fail not only because of the public response but also because of the following aspects: firstly, the candidate has died, second, the candidate has been resigns, and third candidate had legal problems, and was found guilty. But in this study, it was found, one case, that the candidate resign from a party, and moved to another party. Two informants with an LS and LN has resigned from their each previous party, and moved to another party. LN in the election of 2009 is an incumbent of PKS. Then LS is an incumbent of Democratic Party. Both of them declared their resignation from their previous parties and moved into PAN.

The phenomenon of removing these two incumbents, to the Democratic Party, is not a serious problem, for their previous party as long as they complete their administrative requirements as PAN candidates.

Like other candidates, LN and LS were also verified by the Election Committee of Jember. Following the administrative verification, the committee obtained that of all the data of the candidates included in the temporary list of candidates registered by the political parties, only $10 \%$ had complete documents. While the rest $90 \%$ had not met the requirements.

Then to those who had not met the requirements, the committee gave additional time for completing them from 9 May to 22 May 2013. Based on the election commission decision letter No. 315/ KPU/V/2013, political parties are allowed to make amelioration, addition, improvement, and replacement/substitution of the previously registered candidates, including making changes in the ordering number or constituency. Such replacement or substitution should be recorded in the change on the Model Form of BA and $\mathrm{BB}$ until $\mathrm{BB} 11$, regarding the replaced or substituted candidates.

In addition to the incomplete documents, the election committee found that not all of the participating political parties met the requirement of delegating 50 candidates, at the least, for the temporary list, as regulated by the law. For example, PKB only registered 48 candidates, while PDIP registered 47 candidates. Meanwhile, seven of the registered candidates did not meet the requirements; six of which were delegated by PPP and the other one was delegated by PBB. Of the six candidates of PPP, four of which were female. Yet, following the applicable law, the corresponding party still could replace them with other women representatives; therefore the $30 \%$ quota could have been achieved. Meanwhile, the other three failing candidates were male, in that the corresponding political parties were not allowed to replace them with other candidates. Counting the failing candidates, the 
total candidates who passed were 576 people. However, one of them declared his resignation, making the total of the passing candidates decreased to 575 people. Finally, the result of the verification process was delivered to all participating political parties on 7 to 8 May 2013.

Upon the second completion of all documents, the next process was done, that is to announce to the mass media (Radar Jember). This process took about two weeks to obtain enough responses from the society. Fortunately, until the end of the verification period, no objection was received by the committee on all women candidates listed in the temporary list. For this, the election committee went on to switching the status of the candidates in the temporary list to the fixed list of candidates.

The whole mechanism of administrative and factual verification was done by the election committee of Jember in accordance with the applicable regulations. Even better, the bureaucracy implemented by the committee of Jember had been followed diligently by every political party that participated in the election of 2014. Although initially the political parties seemed to be bothered about implementing the policy, they performed every stage of the process successfully. This phenomenon indicates that the success in implementing a policy can possibly be optimized by implementing a distinct policy clause which is coupled with sanctions, as well as a distinct verification.

The result of verification would become an assurance of the party's administrative qualification that it is in accordance with the Law of Election No. 8/2012 and PKPU No. 7/2013. The result of verification indicates that some of the parties failed to meet the predetermined requirements, therefore required improvement. This could happen because the documents to be prepared by the women representatives are abundant, while the time provided to prepare them all is limited; therefore, it just stands to reason that some of the required documents were not prepared yet. Despite this, the attempt of every political party to comply with the policy deserves appreciation. Their compliance to the policy is indicated in the increase of women representatives, that it is against the findings by Bjarnegard, stating that the regulation is incapable of increasing the elected women representatives (Bjarnegard \& Kenny, 2016). But who made the decision, whose determine someone to be a candidate is hard to know because it is in a secret garden (Bjarnegard \& Kenny, 2015).

However, the policy could successfully increase the number of women representatives only if it is completed with distinct sanctions, as written in PKPU No. $7 / 2013$. Yet, these sanctions are not enough; verification is still required to assure that the aim of the policy is implemented. Actually, this data like what Paxton has found. The participation of women in politics will be increased according the the rule of the game (Hughes, Paxton, \& Krook, 2017). This finding is in line with Gwiazda (Gwiazda, 2015), that women's representation policy will increase the women's political participation. It's a kind of fast tarct for women to be candidates.

Administratively, the aforementioned phase is categorized as a phase for the political parties to implement the women representation policy, as regulated in the Law of Election No. 8/2012 and PKPU No. 7/2013. This phase was started by holding a coordinating assembly by the Election Committee of Jember. One of its purposes is to uniform all the visions and missions of the participating political parties regarding the election conduct. Furthermore, the assembly was held in purpose of socializing all applicable regulations for the election days, including ways to implement the women representation policy and achieving the 30\% quota in every constituency. 
Available Online at http://journal.unismuh.ac.id/index.php/otoritas

Otoritas : Jurnal Ilmu Pemerintahan, 8 (1), April, 2018, 41

It is vital to have holistic comprehension towards the two policies, because the women representation policy as implemented in the election of 2014 is different from that implemented in the election of 2004 and 2009. In its implementation in 2004 and 2009, the government did not enact the sanctions for any political parties that failed to reach the $30 \%$ quota. More changes were implemented during the election of 2014. The government started to enact serious sanctions. Should a political party fail to reach the $30 \%$ quota of women representatives in a certain constituency, it is not allowed to participate in the election there. During the socialization, the election committee of Jember provided some technical guidance regarding the policy in order to help all political parties to reach the designated target.

The aforementioned target for every constituency is an obligatory target for every political party. Despite this common target, every party applies different criteria for recruiting a candidate. It would hinge on the vision and mission of the party.

While attempting to reach the $30 \%$ quota, the political parties could not avoid the possibility that cadres of different parties join their parties. One of the applicable requirements is to propose a resignation letter by the cadre to the board of the previous party. Following it, the new party would indicate his/her moving in by giving a member card, thus the movement is legal.

A moving cadre from a political party to another must be under several factors, some of which are the previous party's failure to pass the electoral threshold, and the absence of harmony between the cadre's idealism and the party's; therefore, moving to a different party would be wise. Although the party has lost a cadre due to her movement to another party, no objection from the previous candidate party, which is addressed to the new par- ty of candidates. Legislation, does not prohibit a candidate who moves to another political party.

\section{Achieving the Target of Women Repre- sentation Policy}

The target of $30 \%$ of women candidates is not easily realized by political parties. Political parties are still difficult, in implementing the policy. Women cadres of political parties are limited in number. Even if political parties have women resources, the patriarchal culture of society is still a barrier to women's movement (Bhalotra, Clots-Figueras, \& Iyer, 2017).

On the other hand, every political party is a contestant of the election which aims to be the winner, making them apply more pragmatic requirements when recruiting the candidates. Some put the criteria of candidates in their internal policy, which would be used when they select women. Actually their main target is their own cadre. Should this element not always adequately their targets, so the political party would recruit the noncadres and sympathizers. In this matter, the percentage of candidates taken from the cadre element is different from the other elements. Even a party implemented $10 \%$ of non-cadres of all candidates. This process of selection involves the board and the party winning team.

\section{CONCLUSION}

Since the signing of agreement on the International Convention on the Elimination of All Forms of Discrimination Against Women (CEDAW) on 18 December 1979 and its implementation on September 3, 1981 and the holding of Beijing Declaration, and Platform for Action in 1995, the Indonesian government is trying to implement it through the women representation policy. The policy of women representation was regulated in the Law of Election No. 12/2003 and implemented in the election of 2004. In the 
Available Online at http://journal.unismuh.ac.id/index.php/otoritas

Otoritas : Jurnal Ilmu Pemerintahan, 8 (1), April, 2018, 42

2009 election period, the policy of women's representation that was implemented was regulated in the Election Law no. $10 / 2008$. While the policy of women representation which is implemented in election period of 2014, regulated in the Election Law no. $12 / 2012$. The election commission makes an interpretation of the policy and the results are regulated in PKPU NO. 7/2013. The result of the interpretation is a decision that regulates sanctions for political parties that fail to achieve the target of $30 \%$.

Women's representation policies that had been implemented, during the 2004 and 2009 elections, were weak and powerless, forcing all political parties to implement the policy. But in the election period of 2014, the implementation of women's representation policy, which, regulated by the Election Law no. 8/2012 has been completed by a sanction clause, which is regulated in PKPU No. 72013. In this periode, women's representation policy has the power to force political parties to achieve the target of $30 \%$ of women candidates. The results of policy implementation have effectively increased women's political participation as candidates. Therefore this study, has rejected, the findings of Cornwall (2017), O'Brien \& Rickne (2016), Ndirangu, Onkware, \& Chitere (2017). Patriarchal culture in society, is not a barrier, for women's political participation as candidates. Although, implementing the quota policy is still an early stage. Women, who have been successfully recruited and have become candidates, must still be empowered (Krook, 2016).

\section{ACKNOWLEDGEMENT}

Authors grateful to Postgraduate School of Administrative Science, Faculty of Social and Political Universitas Jember and especially gratefull by Ria Angin to Department of Governmental Science, Faculty of Social and Political Sciences, Universitas Muhammadiyah Jember.

\section{REFERENCES}

Bhalotra, S., Clots-Figueras, I., \& Iyer, L. (2017). Pathbreakers? Women's Electoral Success and Future Political Participation. The Economic Journal. https://doi.org/10.1111/ ecoj.12492

Bjarnegard, E., \& Kenny, M. (2016). Comparing Candidate Selection: A Feminist Institutionalist Approach. Government and Opposition, 51(3), 370-392. https:// doi.org/10.1017/gov.2016.4

Cornwall, A. (2017). The Role of Social and Political Action in Advancing Women's Rights, Empowerment, and Accountability to Women IDS WORKING PAPER. Institute of Development studies (Vol. 2017). Retrieved from https://opendocs.ids.ac.uk/ opendocs/bitstream/ handle/123456789/12996/

Wp488_Online.pdf? sequence $=1 \&$ isAllowed $=y$

Gwiazda, A. (2015). Women's representation and gender quotas: the case of the Polish parliament. Democratization, 22(4), 679-697. https:// doi.org/10.1080/13510347.2013. 869583

Hughes, M. M., Paxton, P., \& Krook, M. L. (2017). Gender Quotas for Legislatures and Corporate Boards. Annual Review of Sociology, 43(1), 331352. https://doi.org/10.1146/ annurev-soc-060116-053324

Kang, A. (2013). The effect of gender quota laws on the election of women: Lessons from Niger. Women's Stud- 
Available Online at http://journal.unismuh.ac.id/index.php/otoritas

Otoritas : Jurnal Ilmu Pemerintahan, 8 (1), April, 2018, 43

ies International Forum, 41, 94-

102. https://doi.org/10.1016/ j.wsif.2013.03.005

Krook, M. L. (2014). Electoral Gender Quotas: A Conceptual Analysis. Comparative Political Studies, 47 (9), 1268-1293. https:// doi.org/10.1177/0010414013495 359

Krook, M. L. (2016). Contesting gender quotas: dynamics of resistance. Politics, Groups, and Identities, 4(2), 268-283. https:// doi.org/10.1080/21565503.2016. 1151797

Mussarat, Jabeen \& Sajid, M. A. (2017). No Title. FWU Journal of Social Sciences, Summer 2017, 11(1), 132-142.

Ndirangu, L. N., Onkware, P. K., \& Chitere, P. P. (2017). Influence of political culture on women participation in politics in Nairobi and Kajiado
Counties Influence of political culture on women participation in Nairobi and Kajiado. The Strategic Journal of Business \& Change Management, 4, 365-380.

O’Brien, D. Z., \& Rickne, J. (2016). Gender quotas and women's political leadership. American Political Science Review, 110(1), 112-126. https:// doi.org/10.1017/ S0003055415000611

Rahmatunnisa, W. (2016). Affirmative Action dan Penguatan Partisipasi Politik Kaum Perempuan di Indonesia. Wacana Politik, 1(2), 90-95.

Rosen, J. (2017). Gender quotas for women in national politics: A comparative analysis across development thresholds. Social Science Research, 66, 82-101. https:// doi.org/10.1016/ j.ssresearch.2017.01.008 